ARTICLE

\title{
Molybdenum isotopes unmask slab dehydration and melting beneath the Mariana arc
}

\author{
Hong-Yan Li (i) ${ }^{1,2,3 凶}$, Rui-Peng Zhao ${ }^{1,4}$, Jie Li, ${ }^{1,2}$, Yoshihiko Tamura (i) ${ }^{5}$, Christopher Spencer (10 ${ }^{6}$, \\ Robert J. Stern (10 ${ }^{7}$, Jeffrey G. Ryan (10 ${ }^{8} \&$ Yi-Gang $X^{1,2,3}$
}

How serpentinites in the forearc mantle and subducted lithosphere become involved in enriching the subarc mantle source of arc magmas is controversial. Here we report molybdenum isotopes for primitive submarine lavas and serpentinites from active volcanoes and serpentinite mud volcanoes in the Mariana arc. These data, in combination with radiogenic isotopes and elemental ratios, allow development of a model whereby shallow, partially serpentinized and subducted forearc mantle transfers fluid and melt from the subducted slab into the subarc mantle. These entrained forearc mantle fragments are further metasomatized by slab fluids/melts derived from the dehydration of serpentinites in the subducted lithospheric slab. Multistage breakdown of serpentinites in the subduction channel ultimately releases fluids/melts that trigger Mariana volcanic front volcanism. Serpentinites dragged down from the forearc mantle are likely exhausted at $>200 \mathrm{~km}$ depth, after which slab-derived serpentinites are responsible for generating slab melts.

\footnotetext{
${ }^{1}$ State Key Laboratory of Isotope Geochemistry, Guangzhou Institute of Geochemistry, Chinese Academy of Sciences, Guangzhou 510640, China. ${ }^{2}$ CAS Center for Excellence in Deep Earth Science, Guangzhou 510640, China. ${ }^{3}$ Southern Marine Science and Engineering Guangdong Laboratory (Guangzhou), Guangzhou 511458, China. ${ }^{4}$ University of Chinese Academy of Sciences, Beijing 100049, China. ${ }^{5}$ Research Institute for Marine Geodynamics (IMG), Japan Agency for Marine-Earth Science and Technology (JAMSTEC), Yokosuka 237-0061, Japan. ${ }^{6}$ Department of Geological Sciences and Geological Engineering, Queen's University, Kingston, ON K7L 3N6, Canada. ${ }^{7}$ Department of Geoscience, University of Texas at Dallas, Richardson, TX 75080, USA. ${ }^{8}$ School of Geosciences, University of South Florida, Tampa, FL 33620, USA. ${ }_{\text {email: hongyanli@gig.ac.cn }}$
} 
$\mathrm{T}$ he Izu-Bonin-Mariana (IBM) arc system stretches over $2800 \mathrm{~km}$ from near Tokyo, Japan to the south of Guam, USA, and is a typical intraoceanic arc system with negligible inputs from sub-arc oceanic crust to the lavas. The IBM system is an endmember non-accreting convergent margin with a thin sedimentary cover on the downgoing slab, which means that input and output fluxes in the subduction zone may be more confidently assessed ${ }^{1}$. The compositions of Mariana arc basalts indicate the involvement of two slab-derived components: an aqueous fluid enriched in fluid mobile elements (FMEs), characterized by high $\mathrm{B} / \mathrm{Nb}, \mathrm{Ba} / \mathrm{Nb}$, and $\mathrm{Pb} / \mathrm{Ce}$; and a hydrous melt, characterized by high $\mathrm{Th} / \mathrm{Nb}$ and $\mathrm{La} / \mathrm{Sm}$ but low $\mathrm{B} / \mathrm{Nb}, \mathrm{Ba} / \mathrm{Nb}$, and $\mathrm{Pb} / \mathrm{Ce}^{2-4}$. The aqueous fluid component has been presumed to derive from the subducted altered mafic oceanic crust (AMOC) based on heavier boron isotopes and more radiogenic $\mathrm{Nd}$ isotopes, indicating a less sediment affected mantle source ${ }^{2,4}$. The hydrous melt component is from subducted sediments, given its high $\mathrm{Th} / \mathrm{Nb}$ and less radiogenic $\mathrm{Nd}$ isotopes ${ }^{2}$. However, the conclusion that AMOC (average ${ }^{87} \mathrm{Sr} /{ }^{86} \mathrm{Sr}=\sim 0.7045^{5}$ ) and marine sediment (average ${ }^{87} \mathrm{Sr} /{ }^{86} \mathrm{Sr}=\sim 0.710^{6}$ ) act as respective sources for the aqueous fluid and hydrous melt is inconsistent with Mariana arc lavas having unradiogenic ${ }^{87} \mathrm{Sr} /{ }^{86} \mathrm{Sr}$ (0.7031-0.7041), and fresh mid-ocean ridge basalt (MORB)-like $\mathrm{Pb}$ isotopes ${ }^{7-10}$, and mantle-like oxygen isotopic compositions ${ }^{11}$. Recent geochemical and geophysical observations suggest that the dehydration of serpentinites may play a more critical role in explaining these observed elemental and isotopic paradoxes. Two kinds of serpentinites may contribute to the mantle source of Mariana arc magmas. The first is serpentinite formed in the shallow forearc mantle at low temperatures $\left(80-250^{\circ} \mathrm{C}\right)$ above the shallow $(<19 \mathrm{~km})$ subducting slab ${ }^{12-16}$. Additions from forearc serpentinites to the sub-arc mantle or subduction channel can explain enrichments of FMEs and heavy boron isotopes (e.g., $\delta^{11} \mathrm{~B}$ from +4.5 to $+12.0 \%$ in the $\left.\operatorname{Izu} \mathrm{Arc}^{17,18}\right)$ in volcanic front basalts, as the slab experiences strong depletions of FMEs before reaching subarc depths ${ }^{15,16,19-21}$. The second serpentinite source is formed via seawater infiltrating oceanic mantle lithosphere along normal faults as the downgoing plate bends down to enter the trench ${ }^{22}$. Fluids resulting from serpentinite dehydration in the slab lithosphere ${ }^{23,24}$ will heat up when rising toward the slab surface. These fluids increase extraction of FMEs from the crust, which could buffer the overall slab fluid/melt $\mathrm{Sr}-\mathrm{Pb}$ isotope signature toward MORB values and also generate FMEenriched signatures $7,8,10,25,26$.

While the importance of serpentinite subduction in the subduction zone chemical cycle is now widely acknowledged, it remains a formidable task to discriminate among these competing models. Which serpentinite sources are responsible, and how they work in the subduction zones are still unclear ${ }^{27,28}$. Molybdenum (Mo) is mobile in fluids, like $\mathrm{Pb}$ and $\mathrm{Ba}$, but it can also be partially retained in rutile during slab dehydration or melting. Mo isotopic fractionation during slab devolatilization results in heavier isotopic signatures in the fluid phase, while the residual slab becomes isotopically lighter ${ }^{8,29-33}$. The materials of the subducting Pacific plate outboard of the Mariana arc have different Mo isotope compositions (expressed as $\delta^{98 / 95} \mathrm{Mo}$, the \%o deviation of ${ }^{98} \mathrm{Mo} /{ }^{95} \mathrm{Mo}$ from standard NIST SRM 3134$)$. AMOC $(-0.12 \%$ to $+0.86 \%$, with a weighted average of $\left.+0.36 \%{ }^{8}\right)$ and marine sediments $(-1.87 \%$ to $+0.11 \%$, with a weighted average of $-0.31 \% 0^{8}$ ) have $\delta^{98 / 95} \mathrm{Mo}$ that are, respectively, higher and lower than the depleted mantle (DM; $\delta^{98 / 95} \mathrm{Mo}=-0.21 \pm 0.02 \%{ }^{34}$ ). Therefore, Mo isotopes may help distinguish among different slab components. This study reports new Mo elemental and isotopic data for well-characterized and very fresh lavas from Pagan and NW Rota-1 volcanoes in the Mariana arc, and serpentinite mud samples from the Asùt Tesoru (formerly Big Blue) Seamount in the Mariana forearc (Fig. 1 and Supplementary Fig. 1). Asùt Tesoru is an active mud volcano erupting serpentinite muds and entrained clasts from the
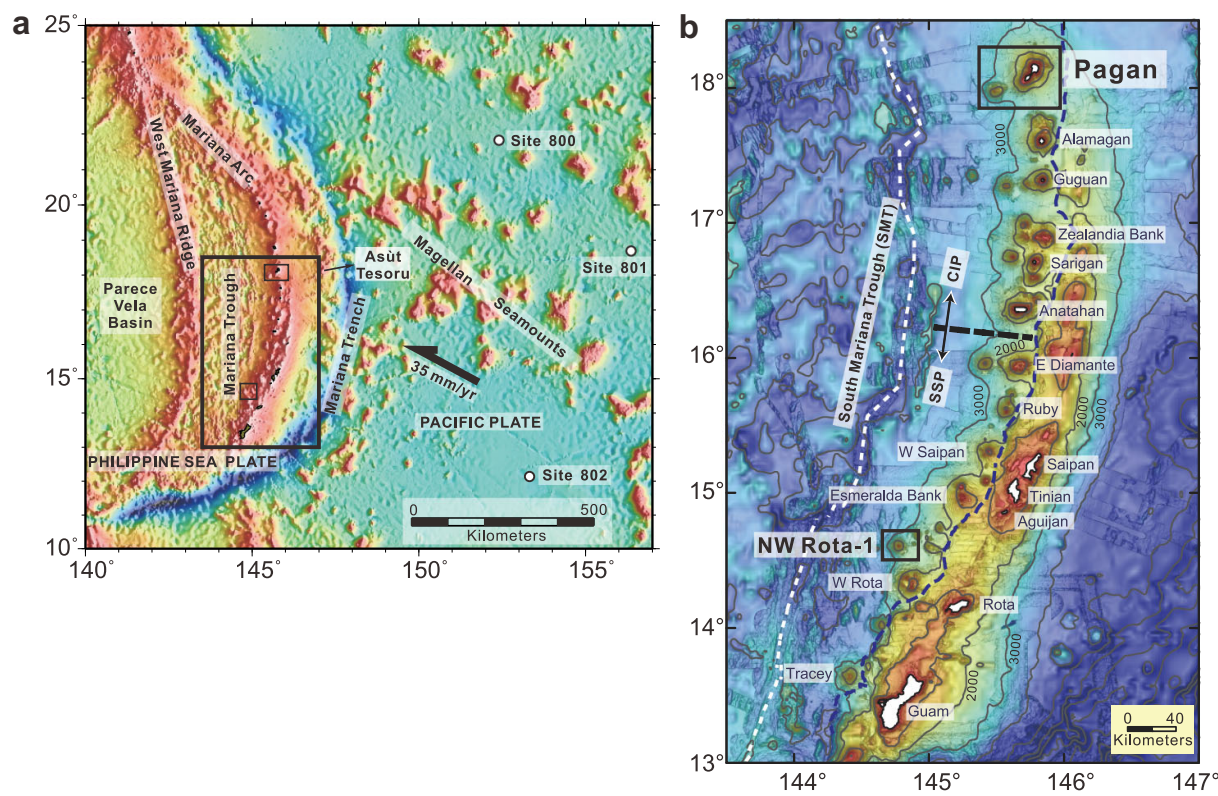

Fig. 1 Regional map of the Mariana convergent plate margin with sampling locations. a Regional map of the Mariana subduction system: the subducting Pacific Plate, Mariana Trench, Mariana Arc, Mariana Trough, West Mariana Ridge, and Parece Vela Basin. The Asùt Tesoru (Big Blue Seamount) mud volcano is located about $72 \mathrm{~km}$ west of the trench axis and $134 \mathrm{~km}$ east of the Pagan volcano and lies about $18 \mathrm{~km}$ above the downgoing Pacific plate ${ }^{13}$. Open circles denote Ocean Drilling Program drill Sites 800, 801, and 802. The rectangle shows the area enlarged in (b). b Map showing the southern Mariana arc, which includes from west to east the Mariana Trough (back-arc basin), the active Mariana arc, the old Mariana forearc (including the islands of Saipan, Tinian, Aguijan, Rota, and Guam), and the Mariana Trench. The white dashed line defines the Mariana Trough spreading ridge. The blue dashed line shows the boundary between the active Mariana arc to the west and the uplifted Mariana frontal arc, part of the Mariana forearc. The maps are from Tamura et al. ${ }^{7}$. SSP Southern Seamount Province, CIP Central Island Province. 
subduction channel, located $\sim 72 \mathrm{~km}$ west of the trench axis and $134 \mathrm{~km}$ east of Pagan Island. Asùt Tesoru is sited $\sim 18 \mathrm{~km}$ above the downgoing plate ${ }^{13}$. Pagan lies along the volcanic front of the Central Island Province, while NW Rota-1 is a submarine volcano located $\sim 40 \mathrm{~km}$ west of the volcanic front of the Southern Seamount Province. Based on the position of the slab beneath these centers $^{35}$, these two volcanoes represent different slab depths ( $120-170 \mathrm{~km}$ vs. $\sim 200-220 \mathrm{~km}$; Supplementary Data 1$)$, so the slab-derived phases should be different (more aqueous fluid beneath Pagan, more hydrous melt beneath NW Rota-1) as NW Rota-1 has a higher corresponding slab temperature than Pagan volcano. Both erupt little-fractionated high $\mathrm{MgO}$ basalts, which is unusual in $\operatorname{arcs}^{7,36}$.

Here, we show that serpentinites formed in both the forearc mantle and the slab lithosphere are both important for generating subduction zone fluids/melts. Upper plate serpentinites transported down along the slab interface may be an important intermediate carrier for slab fluid and melt transfer in the subduction channel. Dehydration of serpentinites in the subducted lithospheric slab is critical for triggering melting at depth.

\section{Results}

Mo and $\delta^{\mathbf{9 8 / 9 5}}$ Mo of the volcanic lava and serpentinite mud samples. Pagan and NW Rota-1 lavas reflect a wide range of magmatic fractionation, with $\mathrm{MgO}$ contents from 11.2 to $2.2 \mathrm{wt} \%$ (Fig. 2), allowing for evaluation of fractional crystallization effects on the Mo contents and isotopes of the lavas. The ranges in Mo contents among Pagan and NW Rota-1 samples at $\mathrm{MgO}>7 \mathrm{wt} \%$ are similar $(0.3-0.6 \mu \mathrm{g} / \mathrm{g}$ vs. $0.3-0.45 \mu \mathrm{g} / \mathrm{g})$. However, the Pagan Southwestern (SW) Flank samples have higher Mo contents $(1.0-1.9 \mu \mathrm{g} / \mathrm{g})$ at $<7 \mathrm{wt} \% \mathrm{MgO}$ than do the NW Rota-1 samples $(0.44-1.1 \mu \mathrm{g} / \mathrm{g})$, suggesting different magmatic evolution processes (Fig. 2a). Negative correlations between $\mathrm{Mo}$ and $\mathrm{MgO}$ imply that Mo behaves as a moderately incompatible element during mantle melting and magmatic differentiation, similar to the light rare earth elements. Thus, Ce/Mo ratios can be used to document Mo enrichment in volcanic rocks or their mantle sources $8,30,31,33$. The SW Pagan samples point to complex magmatic evolution, including magma mixing, as indicated by reverse-zoned olivine and clinopyroxene phenocrysts ${ }^{7}$. The Dy/ $\mathrm{Yb}$ of these samples decrease with decreasing $\mathrm{MgO}$ (Fig. 2b) and their Hf/Nd increase (Supplementary Fig. 2), suggesting fractional crystallization of amphibole from the evolved mixing component ${ }^{37,38}$. Ce/Mo ratios correlate positively with $\mathrm{MgO}$ in SW Pagan samples, while $\delta^{98 / 95}$ Mo correlates inversely (Fig. 2c, d), suggesting that amphibole crystallization and/or mixing decreases $\mathrm{Ce} / \mathrm{Mo}$ and increases $\delta^{98 / 95} \mathrm{Mo}$ with magmatic evolution. This fractionation trend is consistent with observations from differentiated arc lavas in other localities ${ }^{39-41}$.

$\mathrm{Dy} / \mathrm{Yb}$ and $\mathrm{Hf} / \mathrm{Nd}$ show no clear correlation with $\mathrm{MgO}$ in the Eastern Flank or Summit samples of NW Rota-1 (Fig. 2b and Supplementary Fig. 2), indicating that the effects of amphibole crystallization are not significant. The East Knoll samples of NW Rota-1 vary little in $\mathrm{MgO}$, making it difficult to evaluate fractional crystallization effects. However, they have similar Dy/Yb and Hf/ $\mathrm{Nd}$ to other evolved NW Rota-1 samples (Fig. $2 \mathrm{~b}$ and Supplementary Fig. 2), suggesting amphibole crystallization did not play a major role in their compositions. The evolved samples ( $<7 \mathrm{wt} \% \mathrm{MgO}$ ) from SW Pagan are excluded from the following discussion, to avoid the complexities introduced by fractional crystallization and/or mixing effects.

Pagan and NW Rota-1 samples that are unaffected by amphibole crystallization range in $\delta^{98 / 95} \mathrm{Mo}$ from $-0.31 \%$ to $+0.19 \%$ o (Fig. 3), with values both higher and lower than that of $\mathrm{DM}\left(-0.21 \pm 0.02 \% 0^{34,42}\right)$. This $\delta^{98 / 95} \mathrm{Mo}$ variation is much greater than has been observed in comparable Mariana arc lavas from the Central Island province (MgO: $2.7-6.1 \mathrm{wt} \% ; \delta^{98 / 95} \mathrm{Mo}=-0.17 \%$ to $\left.+0.15 \%{ }^{8}\right)$ or in lavas from the Izu volcanic front $(\mathrm{MgO}$
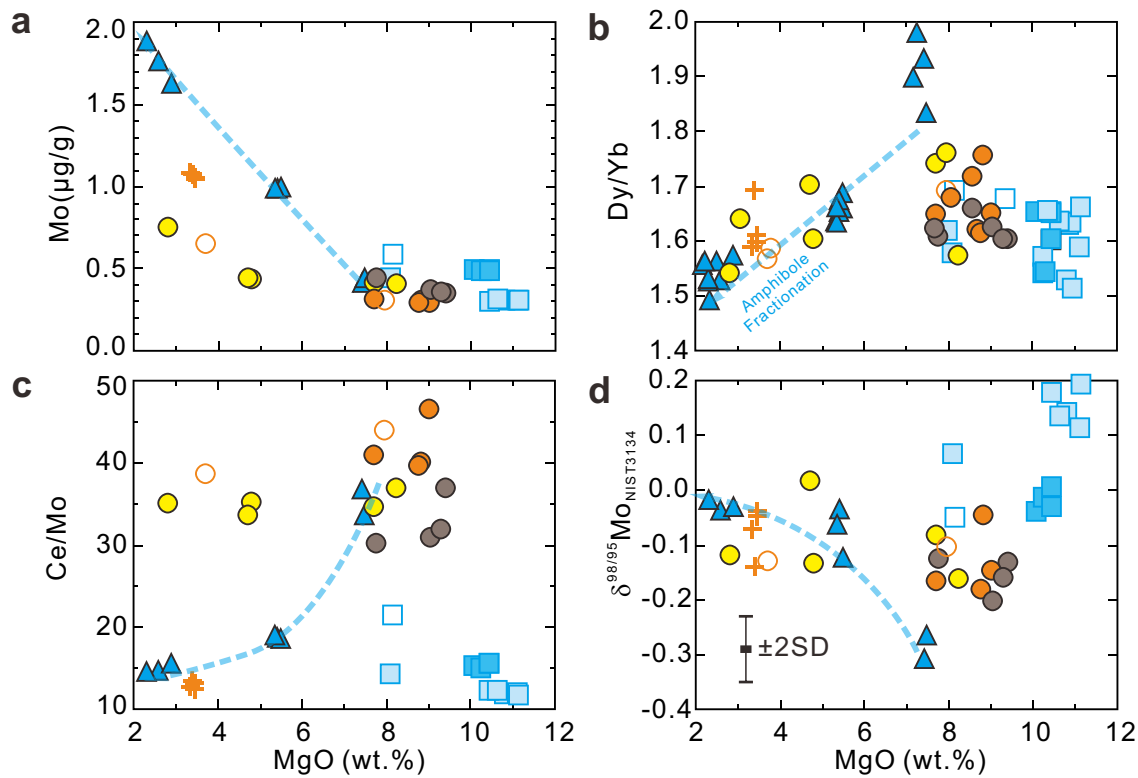

\begin{tabular}{llll}
\multirow{2}{*}{ Pagan } & $\square$ Northeastern Flank(COB1) & $\square$ Northeastern Flank (Others) \\
& $\square$ Northeastern Flank(COB2) & $\triangle$ Southwestern Flank \\
\hline \multirow{2}{*}{ NW Rota-1 $\bigcirc$ Eastern Flank (COB) } & $\bigcirc$ Eastern Flank (POB) \\
& Eastern Flank (Others) & $\bigcirc$ Summit $\quad+$ East Knoll
\end{tabular}

Fig. 2 Chemical variations due to magmatic evolution to form Pagan and NW Rota-1 volcanic rocks. Plots of a Mo, b Dy/Yb, c Ce/Mo, and $\mathbf{d} \delta^{98 / 95} \mathrm{Mo}$ vs. MgO diagrams for the Pagan and NW Rota-1 samples. COB clinopyroxene-olivine basalt, POB plagioclase-olivine basalt, SD standard deviation, which is based on duplicate analyses of standard solution NIST SRM 3134, reference materials AGV-2 and W-2a, IAPSO seawater standard, and unknown samples. 

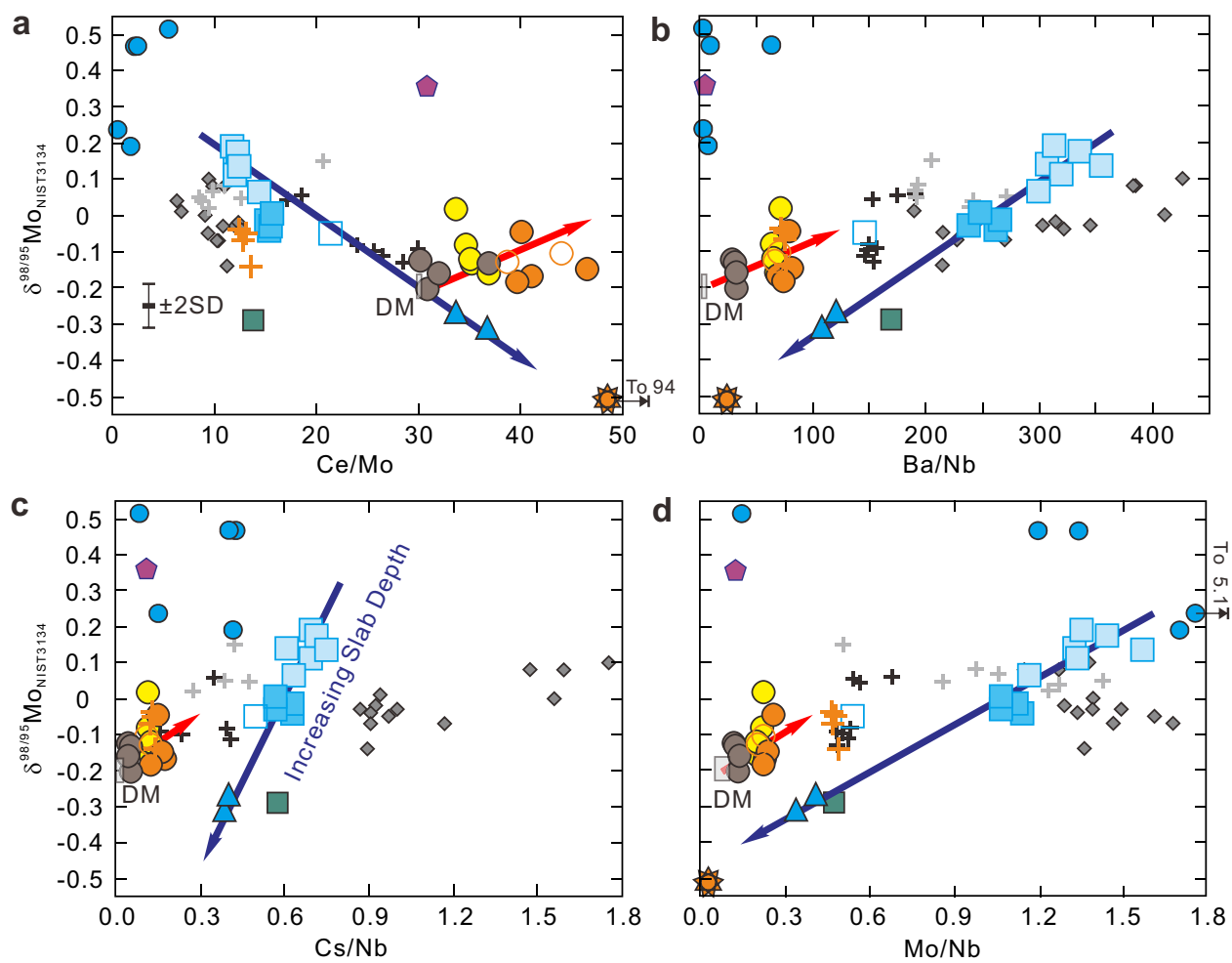

Asùt Tesoru mud volcano

\begin{tabular}{lll}
\hline Pagan & $\square$ Northeastern Flank(COB1) & $\square$ Northeastern Flank (Others) \\
& $\square$ Northeastern Flank(COB2) & $\triangle$ Southwestern Flank \\
\hline NW Rota-1 $\bigcirc$ Eastern Flank (COB) & $\bigcirc$ Eastern Flank (POB) \\
& Eastern Flank (Others) & $\bigcirc$ Summit \\
\hline Eclogite $\triangle$ Average AMOC & $\square$ Average Mariana Sediments \\
+ Alamagan and Guguan + Agrigan and Uracas
\end{tabular}

Fig. 3 Mo isotope and trace element systematics of serpentinite mud and volcanic rock samples. Plots of $\delta^{98 / 95} \mathrm{Mo} v \mathrm{vs}$ a $\mathrm{Ce} / \mathrm{Mo}$, b $\mathrm{Ba} / \mathrm{Nb}, \mathbf{c} \mathrm{Cs} / \mathrm{Nb}$, and d $\mathrm{Mo} / \mathrm{Nb}$ for the Asùt Tesoru serpentinite mud samples and Pagan and NW Rota-1 volcanic rock samples unaffected by amphibole fractional crystallization. The Izu arc ${ }^{33}$, other Mariana volcanic front volcanoes ${ }^{8}$, average Mariana sediments $6,8,801 \mathrm{C}$ AMOC Super Composite ${ }^{8,72}$ and average blueschist and eclogite data from the Raspas Complex and Cabo Ortegal Complex ${ }^{32}$ are also plotted for comparison. The ranges for depleted mantle (DM) are estimated according to the studies of Bezard et al. ${ }^{34}$, Gale et al. ${ }^{44}$, Workman and Hart ${ }^{73}$, and Salters and Stracke ${ }^{43}$. COB clinopyroxene-olivine basalt, POB plagioclase-olivine basalt, AMOC altered mafic oceanic crust, SD standard deviation. The blue arrows show compositions of magmas formed above increasing slab depth.

3.4-5.6 wt $\%$; $\delta^{98 / 95} \mathrm{Mo}=-0.14 \%$ o to $\left.+0.11 \%{ }^{33}\right)$. The NW Rota-1 samples are lower in $\delta^{98 / 95} \mathrm{Mo}$, from $-0.20 \%$ to $-0.02 \%$, and show a smaller $\delta^{98 / 95} \mathrm{Mo}$ range $(0.18 \%$ o $\pm 0.12 \%$ o $)$ than either the Pagan samples $(0.4 \% \pm 0.12 \%$ o $)$ or other IBM samples $(0.32 \%$ $\pm 0.12 \%$ o). The Pagan and NW Rota-1 samples also show greater variation in Ce/Mo (11.8-46.5) than other Mariana arc (8.5-29.9) or Izu arc lavas (6.3-12.7; Fig. 3a), suggesting greater variability in magma source compositions. $\delta^{98 / 95}$ Mo in the Pagan samples correlate with aqueous fluid proxies, e.g., $\mathrm{Ba} / \mathrm{Nb}$ and $\mathrm{Cs} /$ $\mathrm{Nb}$ ratios (Fig. 3b, c), consistent with an isotopically heavy Mo signature arising from slab dehydration. $\delta^{98 / 95} \mathrm{Mo}$ and $\mathrm{Ce} / \mathrm{Mo}$ correlate inversely in the Pagan samples and show a much steeper trend than other Mariana and Izu volcanic front samples ${ }^{8,33}$, suggesting a fluid-derived $\delta^{98 / 95} \mathrm{Mo}$ component that is much higher than $+0.2 \%$ o.

All the NW Rota-1 samples save those from its East Knoll are similar in their trace element and Mo isotopic variations to the Pagan samples, in that $\mathrm{Ba} / \mathrm{Nb}, \mathrm{Cs} / \mathrm{Nb}$, and $\mathrm{Mo} / \mathrm{Nb}$ are all higher than DM and correlate with $\delta^{98 / 95}$ Mo (Fig. 3b-d), although they have somewhat higher Ce/Mo than DM $\left(\sim 31^{43}\right)$. This observation indicates that the slab beneath NW Rota-1 may already be significantly Mo depleted as a result of early dehydration. This deeper slab source may thus be similar to the eclogites from the Cabo Ortegal Complex in Spain, which experienced peak metamorphic conditions of $>1.7 \mathrm{GPa}$ and $650-670{ }^{\circ} \mathrm{C}$, and have much lower Mo contents than average MORB (0.19 vs. $0.46 \mu \mathrm{g} /$ $\left.\mathrm{g}^{32,44}\right)$. Two of the SW Pagan samples have slightly higher Ce/Mo than DM and are much lower in $\delta^{98 / 95}$ Mo than any of the NW Rota-1 samples. The East Knoll samples of NW Rota-1 have lower Ce/Mo than others from this center (Fig. 3a), possibly related to the greater Mo enrichment of their sources (Fig. 2a).

The three volcanic sample sites examined in this study reflect increasing distances from the trench, and therefore increasing depth to slab, in the following order: northeastern (NE) Pagan (124.5-129 km), SW Pagan (167-168 km), NW Rota-1 (198-223 km; Supplementary Data 1). A gradual reduction in fluid signatures with increasing slab depth (e.g., $\delta^{98 / 95} \mathrm{Mo}, \mathrm{Ce} / \mathrm{Mo}$, and $\mathrm{Ba} / \mathrm{Nb}$ ) and increases in melt signatures (e.g., Hf/Nd; Fig. 4) indicate that the slab input correlates to slab temperature, evolving from a hydrous fluid-dominated phase to one that is 

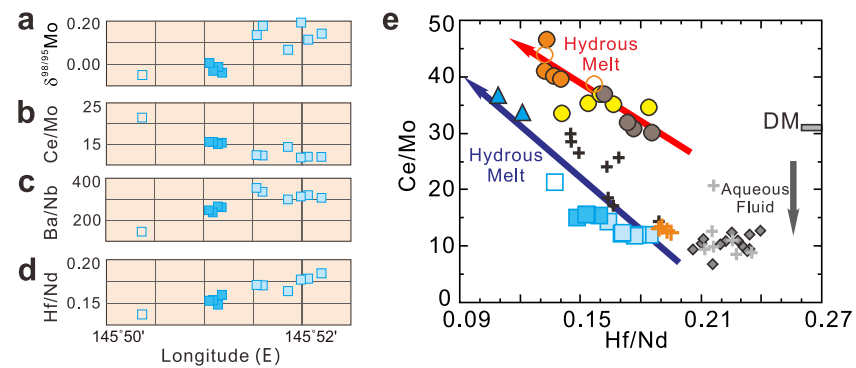

Fig. 4 Chemical variations of Pagan volcanic rocks as a function of longitude and plot of $\mathrm{Ce} / \mathrm{Mo}$ vs. Hf/Nd for Pagan and NW Rota-1 samples. Plots of a $\delta^{98 / 95} \mathrm{Mo}, \mathbf{b} \mathrm{Ce} / \mathrm{Mo}, \mathbf{c} \mathrm{Ba} / \mathrm{Nb}$, and $\mathbf{d} \mathrm{Hf} / \mathrm{Nd}$ vs. longitude for the NE Pagan samples, and e $\mathrm{Ce} / \mathrm{Mo}$ vs. Hf/Nd for the Pagan and NW Rota-1 samples unaffected by amphibole fractional crystallization. The Izu arc and other Mariana volcanic front volcanoes data are also plotted for comparison. The ranges for depleted mantle (DM) are estimated according to the studies of Workman and Hart ${ }^{73}$ and Salters and Stracke $^{43}$. The blue arrows show compositions of magmas formed above increasing slab depth. The symbols and data source are as in Fig. 3.

melt dominated ${ }^{3,21,45-47}$. The samples from NE Pagan have a wide range of $\delta^{98 / 95} \mathrm{Mo}$ associated with more radiogenic Hf and $\mathrm{Nd}$ isotopes, but also with more radiogenic $\mathrm{Sr}$ and $\mathrm{Pb}$ isotopes as compared to the primitive NW-Rota-1 samples (Figs. 5 and 6). Radiogenic $\mathrm{Hf}$ and $\mathrm{Nd}$ isotopes are expected for melts derived from a depleted mantle source metasomatized by slab-derived aqueous fluids with negligible Hf-Nd contents. By contrast, the less radiogenic $\mathrm{Hf}$ and $\mathrm{Nd}$ of the primitive NW Rota-1 samples is expected for melts derived from a less depleted mantle, or from mantle metasomatized by a slab melt with contributions from subducting sediments. Mo isotopes reflect this fundamental difference, with higher $\delta^{98 / 95} \mathrm{Mo}$ in fluid-dominated NE Pagan samples and lower $\delta^{98 / 95}$ Mo for slab melt-dominated NW Rota-1 samples. The Pagan samples show that $\delta^{98 / 95}$ Mo correlates with $\mathrm{Hf}$ and $\mathrm{Nd}$ isotopes, albeit with limited $\mathrm{Sr}$ or $\mathrm{Pb}$ isotope variation. NW Rota-1 samples differ in that $\delta^{98 / 95} \mathrm{Mo}$ is generally positively correlated with ${ }^{87} \mathrm{Sr} /{ }^{86} \mathrm{Sr}$ and ${ }^{206} \mathrm{~Pb} /{ }^{204} \mathrm{~Pb}$, but is not regularly correlated with $\mathrm{Hf}$ or $\mathrm{Nd}$ isotopes (Figs. 5 and 6).

The Asùt Tesoru serpentinite mud samples, which are associated with the highest Mo pore fluids among the analyzed serpentinite mud volcanoes in the Mariana forearc ${ }^{48}$, have Mo contents from 0.1 to $1.3 \mu \mathrm{g} / \mathrm{g}$ and Ce/Mo from 0.5 to 5.5 (Fig. 3a; Supplementary Data 1). Their Mo contents are much higher and their Ce/Mo are much lower than DM $\left(\mathrm{Mo}=\sim 0.025 \mu \mathrm{g} / \mathrm{g}, \mathrm{Ce} / \mathrm{Mo}=\sim 31^{43}\right)$. These samples show consistently high $\delta^{98 / 95} \mathrm{Mo}$, from $+0.19 \%$ to $+0.52 \%$ o (Fig. 3; Supplementary Data 1), much higher than DM. These data indicate mobilization of Mo from the slab under low P-T conditions in hydrous fluids $\left(\sim 18 \mathrm{~km} ; \sim 250^{\circ} \mathrm{C}^{13,48}\right)$, and that Mo mobilized under these conditions is high $\delta^{98 / 95}$ Mo. In Fig. 3, the Asùt Tesoru serpentinite muds appear to be consistent with the high $\delta^{98 / 95} \mathrm{Mo}$ endmember of the IBM arc lavas. However, they also have comparatively low $\mathrm{Ba} / \mathrm{Nb}$ and $\mathrm{Cs} / \mathrm{Nb}$ (Fig. 3).

Tracking slab fluid and melt components for Pagan volcano. The Mo isotope signatures of aqueous fluids from the subducting slab have been studied previously $8,30,33$. The wide variations in $\mathrm{Ce} / \mathrm{Mo}$ and $\delta^{98 / 95} \mathrm{Mo}$, and especially their correlations with aqueous fluid and hydrous melting proxies in this study, allow us to further discriminate among slab-derived fluid and melt signatures. The Mo isotopes of Pagan samples can be modeled as a two-component mixing array (Figs. $3-5$ ). The high $\delta^{98 / 95} \mathrm{Mo}$ and low Ce/Mo signatures in NE Pagan samples largely reflect aqueous fluid contributions from the slab, given their correlations with other fluid proxies such as $\mathrm{Mo} / \mathrm{Nb}, \mathrm{Ba} / \mathrm{Nb}$, and $\mathrm{Cs} / \mathrm{Nb}^{8,33}$. This fluid component is similar to the Asùt Tesoru serpentinites in that they have high $\delta^{98 / 95} \mathrm{Mo}$, low $\mathrm{Ce} / \mathrm{Mo}$, and high $\mathrm{Mo} / \mathrm{Nb}$. However, the high $\mathrm{Cs} / \mathrm{Nb}$ and $\mathrm{Ba} / \mathrm{Nb}$ signature of Mariana arc lavas (Fig. 3) are difficult to explain through serpentinite inputs alone, as Cs is only moderately (25 to $30 \%$ ) while $\mathrm{Ba}$ is only slightly $(<2 \%)$ mobile off the subducting slab at $10-40 \mathrm{~km}$ depths ${ }^{15,16}$. Further metasomatism of arc sources by slab fluids released at depths $>40 \mathrm{~km}$ is necessary, under slab thermal conditions hot enough to mobilize $\mathrm{Ba}$. While this fluid component has $\delta^{98 / 95} \mathrm{Mo}$ akin to AMOC (average $\left.\delta^{98 / 95} \mathrm{Mo}=+0.36 \%{ }^{8}\right)$, its unradiogenic ${ }^{87} \mathrm{Sr} /{ }^{86} \mathrm{Sr}(\sim 0.7035)$ and unaltered MORB-like $\mathrm{Pb}$ isotopes $(\Delta 8 / 4>-4$; Fig. $6 \mathrm{c})$ rule out a dominant role for AMOC as a source $\mathrm{e}^{7,8,10}$. These isotopic observations have recently been accounted for via inputs from the breakdown of serpentinite in the slab lithosphere, which releases fluids that percolate through and equilibrate with overlying oceanic crust, buffering its $\mathrm{Pb}-\mathrm{Sr}$ isotopes toward that of $\mathrm{MORB}^{7,8,10}$. Isotopic fractionation between the fluid and residual slab material can generate the $\delta^{98 / 95} \mathrm{Mo}$ signature of the fluid component evidenced in samples from NE Pagan $^{8}$.

The second mixing endmember has low $\delta^{98 / 95} \mathrm{Mo}(\sim-0.31 \%$ ) with higher $\mathrm{Ce} / \mathrm{Mo}$, low $\mathrm{Ba} / \mathrm{Nb}, \mathrm{Cs} / \mathrm{Nb}$, and $\mathrm{Mo} / \mathrm{Nb}$, and less radiogenic $\mathrm{Hf}-\mathrm{Nd}$ isotopes (Figs. 3 and 5). This endmember appears most consistent with a slab melt component. The positive correlation between $\delta^{98 / 95} \mathrm{Mo}$ and $\varepsilon \mathrm{Hf}$ suggests a relationship between the addition of aqueous fluids and compositional heterogeneity of the sub-arc mantle, i.e., more aqueous fluid flux must be added to a more depleted and refractory sub-arc mantle for melting to occur ${ }^{33}$. However, the $\delta^{98 / 95}$ Mo of primitive Pagan samples also correlate with $\mathrm{Hf} / \mathrm{Nd}$, a proxy for hydrous melt inputs from the $\mathrm{slab}^{49-51}$. This slab melt component has an $\mathrm{Nd}-\mathrm{Hf}$ isotope signature akin to the Indian mantle domain as opposed to subducted Pacific crust (Fig. 5c). One can resolve these trace element and isotopic features via the addition of $\approx 10 \mathrm{wt} \%$ sediments to the melted slab ${ }^{50,52-55}$ (Fig. 5c and Supplementary Fig. 3). The amount of subducted sediment contribution is limited by the samples' low ${ }^{87} \mathrm{Sr} /{ }^{86} \mathrm{Sr}$ and ${ }^{206} \mathrm{~Pb} /{ }^{204} \mathrm{~Pb}$, which as noted above are consistent with an evolved serpentinite fluid contribution in which $\mathrm{Sr}-\mathrm{Pb}$ isotopes are buffered toward MORB-like values ${ }^{10,25,26}$ (Fig. 6).

Therefore, both the signatures of aqueous slab fluids and hydrous slab melts may be derived in different proportions from the different slab constituents (wedge and slab serpentinite, basalt, and sediments), and increasing slab temperatures with depth should control the generation of fluids and melts. How slab fluids and melts are injected into the sources of arc melting is still unclear, although their geochemical signatures are readily discriminated $7,21,25,26$. The most straightforward model is one in which Mo-Nd-Hf elemental and isotopic variations of Pagan magmas are controlled by the slab surface temperature, i.e., slab inputs richer in fluids gradually evolve toward a more hydrous melt signature with increasing slab depth. However, NE Pagan samples show clear differences in slab input with very little corresponding slab depth variation, $124.5-129 \mathrm{~km}^{35}$ (Supplementary Data 1). Significant slab temperature variation over such a narrow depth range is unlikely ${ }^{56}$. Based on major and trace element and radiogenic isotope results, Tamura et al. ${ }^{7}$ proposed that aqueous fluid and hydrous melt components unmix from an originally homogeneous supercritical fluid in or above the subducting slab below Pagan volcano. The geochemical diversity of the basalts erupted at NE and SW Pagan becomes possible if these two unmixed components are added separately to the mantle beneath the Pagan volcano. However, this explanation fails to explain the observed Mo isotope variations, including values both 

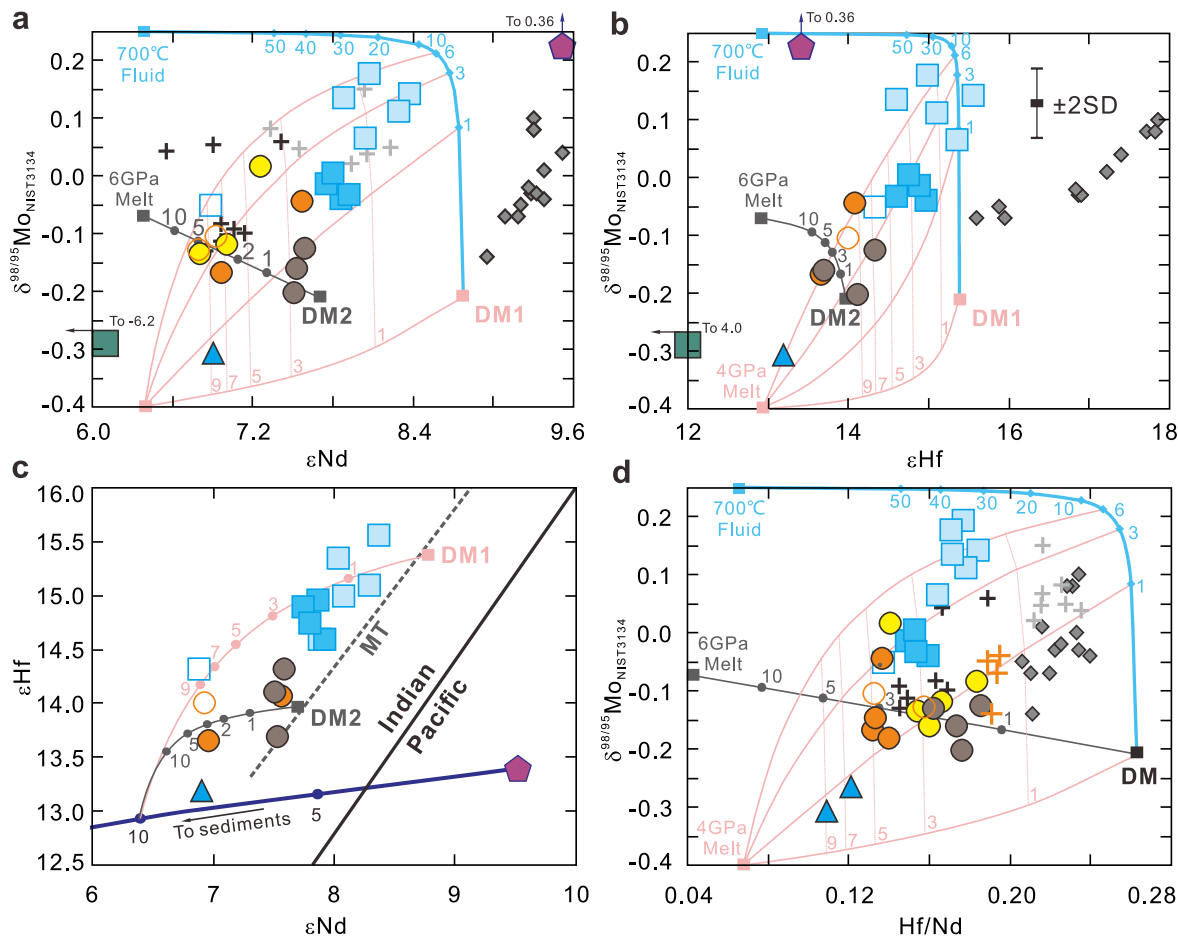

Fig. 5 Mo, Nd, and Hf isotopes and Hf/Nd of Pagan and NW Rota-1 volcanic rocks. Plots of a $\delta^{98 / 95} \mathrm{Mo} v$ s. $\varepsilon \mathrm{Nd}$, b $\delta^{98 / 95} \mathrm{Mo}$ vs. $\varepsilon \mathrm{Hf}$, c $\varepsilon \mathrm{Hf}$ vs. $\varepsilon \mathrm{Nd}$, and $\mathbf{d}$ $\delta^{98 / 95} \mathrm{Mo}$ vs. $\mathrm{Hf} / \mathrm{Nd}$ for the Pagan and NW Rota-1 samples unaffected by amphibole fractional crystallization, illustrating the slab dehydration/melting process. The Izu, other Mariana volcanic front, average Mariana sediments, and $801 \mathrm{C} \mathrm{AMOC} \mathrm{Super} \mathrm{Composite} \mathrm{data} \mathrm{are} \mathrm{also} \mathrm{plotted} \mathrm{for} \mathrm{comparison.} \mathrm{The}$ depleted mantle 1 (DM1), DM2, $700{ }^{\circ} \mathrm{C}$ slab fluid, $4 \mathrm{GPa}$ slab melt, and $6 \mathrm{GPa}$ slab melt compositions are listed in Supplementary Table 1. The numbers on the mixing curves between different compositions represent the mass percentage of the slab fluid/melt. The solid black line in (c) is the boundary of $\mathrm{Hf}-\mathrm{Nd}$ isotopic composition between the Indian and Pacific Ocean mantle domains 50,54 . The Hf-Nd isotopic trend of the Mariana Trough (MT) mantle is according to Woodhead et al. ${ }^{53}$. SD standard deviation. The symbols and data source are as in Fig. 3.
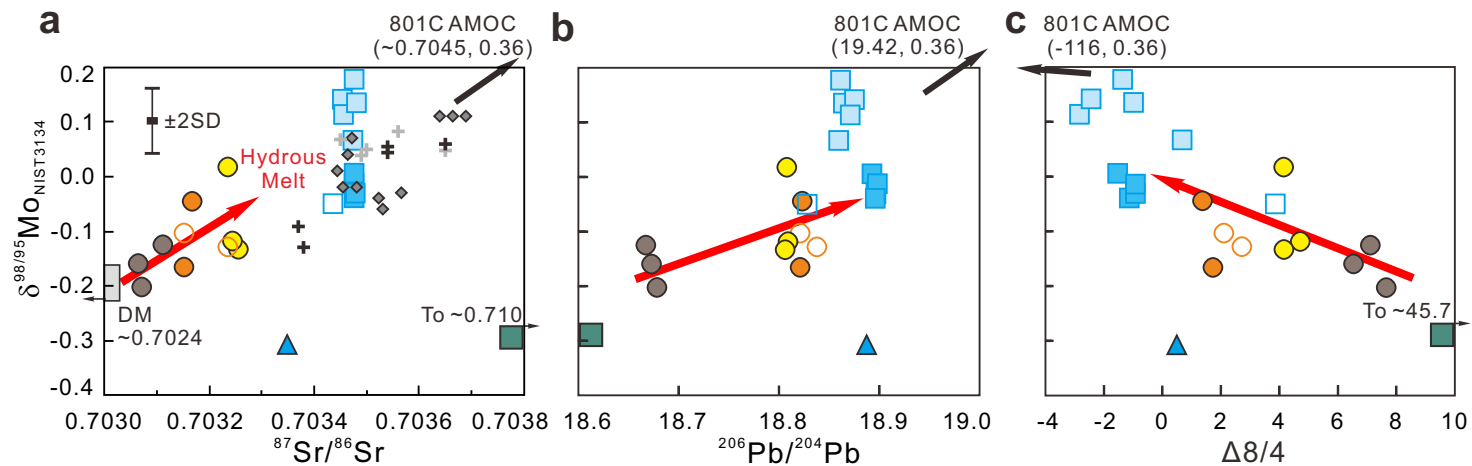

Fig. 6 Mo, Sr, and Pb isotopes of Pagan and NW Rota-1 volcanic rocks. Plots of a $\delta^{98 / 95} \mathrm{Mo} v \mathrm{~s} .{ }^{87} \mathrm{Sr} / 86 \mathrm{Sr}$, b $\delta^{98 / 95} \mathrm{Mo} v \mathrm{v} .{ }^{206} \mathrm{~Pb} /{ }^{204} \mathrm{~Pb}$ and $\mathbf{c} \delta^{98 / 95} \mathrm{Mo}$ vs. $\Delta 8 / 4$ for the Pagan and NW Rota-1 samples unaffected by amphibole fractional crystallization. $\Delta 8 / 4$ is the displacement from the Northern Hemisphere Reference Line in ${ }^{208} \mathrm{~Pb} /{ }^{204} \mathrm{~Pb}-{ }^{206} \mathrm{~Pb} /{ }^{204} \mathrm{~Pb}$ space ${ }^{74}$. The $\mathrm{Sr}-\mathrm{Mo}$ isotopes of the depleted mantle (DM) are estimated according to the study on Pacific-Antarctic ridge basalts ${ }^{34}$. The Izu, other Mariana volcanic front, and average Mariana sediments data are also plotted for comparison. The ranges for the average $801 \mathrm{C} \mathrm{AMOC5,8,52}$ run off of the diagrams. The symbols and data source are as in Fig. 3. SD standard deviation, AMOC altered mafic oceanic crust.

higher and lower than DM, and a decrease in $\delta^{98 / 95} \mathrm{Mo}$, from $+0.19 \%$ o to $-0.31 \%$, correlated with the slab depths beneath the knolls (Fig. 4), as the two unmixed components should have similar Mo isotopes.

We conducted quantitative mixing calculations based on Mo-Hf-Nd elemental and isotopic systematics to address this problem. Detailed input parameters and calculated slab components for the Mariana arc lavas are listed in Supplementary Table 1. From $\varepsilon H f$, $\varepsilon \mathrm{Nd}$, and $\mathrm{Hf} / \mathrm{Nd}$ systematics, the slab surface is estimated to be comprised of AMOC and sediments in a ratio of 9:1, and the ambient mantle has $\varepsilon N d$ between 7.7 and 9.7 (Fig. 5c and Supplementary Fig. 3). Elemental abundances in the shallow slab fluid $\left(700^{\circ} \mathrm{C}\right)$ and slab melt $\left(900^{\circ} \mathrm{C}, 4 \mathrm{GPa}\right)$ are calculated according to the liquid-eclogite partition coefficients of Kessel et al. ${ }^{49}$, assuming modal batch dehydration/melting at $F=2 \%$ and $F=10 \%$, respectively. The shallow slab fluid $\delta^{98 / 95} \mathrm{Mo}$ is estimated to be the same as that for the Izu arc $\left(+0.25 \% 0^{33}\right)$, while its Mo content is constrained by the uniform $\mathrm{Ba} / \mathrm{Mo}=230$ for $\mathrm{NE}$ Pagan samples and the calculated $\mathrm{Ba}$ content for the fluid. The oceanic crust during melting is inferred to have the same average Ce/Mo and $\delta^{98 / 95} \mathrm{Mo}$ as those of 
blueschists and eclogites from the Raspas Complex and Cabo Ortegal Complex $^{32}$. Slab melt Mo is calculated using the liquid-mineral Mo partition coefficients of Chen et al. ${ }^{32}$ and Adam and Green ${ }^{57}$, assuming $2 \mathrm{wt} \%$ rutile in the slab, and a clinopyroxene:garnet ratio of 7:3. The Mo isotope fractionation factor is calculated according to the experimental result of $\Delta^{98 / 95} \mathrm{Mo}_{\text {melt-rutile }}=0.33 \pm 0.06 \%$ at $1175^{\circ} \mathrm{C}$ between the melt and the residual rutile ${ }^{32}$. Our calculations show that a slab melt at $4 \mathrm{GPa}$ has $\delta^{98 / 95} \mathrm{Mo}$ of $-0.4 \%$, slightly lower than the lowest SW Pagan sample $(-0.31 \%$ ), Ce/Mo of $\sim 43$, slightly higher than the highest SW Pagan sample ( 37), and Hf/Nd of $\sim 0.07$, similar to that estimated for the slab melt component (Fig. $5 \mathrm{~d}$ and Supplementary Fig. 3). The results also indicate a deep lithosphere fluid flux is not necessary for slab melting beneath SW Pagan, because it would be difficult to get the high Ce/Mo signature of the melt. The $\mathrm{Sr}-\mathrm{Pb}$ isotopes of the melted slab may have been buffered toward the MORB values as a result of long-term early lithosphere fluid percolation at shallow depth.

Our calculations demonstrate that solely low-temperature slab fluid inputs cannot explain the low $\mathrm{Hf} / \mathrm{Nd}$ characteristics of $\mathrm{NE}$ Pagan samples. An upper-mantle source would require $\sim 30-40 \mathrm{wt} \%$ input of a $700^{\circ} \mathrm{C}$ slab fluid or $\sim 20 \mathrm{wt} \%$ input of an $800{ }^{\circ} \mathrm{C}$ slab fluid to lower its $\mathrm{Hf} / \mathrm{Nd}$ from DM-like values, as $\mathrm{Hf}$ and $\mathrm{Nd}$ are so poorly mobilized in fluids, even at $700-800^{\circ} \mathrm{C}$ (Fig. 5d). The constraints from $\mathrm{Hf} / \mathrm{Nd}$ are independent of any estimation for Mo isotopes in a shallow slab fluid. Such a high percentage of slab addition is likely impossible, especially considering that the NE Pagan has a corresponding slab depth $>120 \mathrm{~km}$. Although the role of mixing slab components into the mantle wedge or mixing of magmas in the plumbing system cannot be fully ruled out ${ }^{58}$, this does not explain the $\mathrm{Th} / \mathrm{Nb}$ versus $\mathrm{Pb} / \mathrm{Ce}$ variation in the Pagan samples (Supplementary Fig. 4). A more plausible explanation is that the source material for the Pagan samples was first metasomatized by $1-6 \%$ aqueous fluid with high $\delta^{98 / 95} \mathrm{Mo}$, and is then fluxed by $1-9 \%$ hydrous melt with low $\delta^{98 / 95} \mathrm{Mo}, \mathrm{Hf} / \mathrm{Nd}, \varepsilon \mathrm{Nd}$, and $\varepsilon \mathrm{Hf}$ (Fig. 5 and Supplementary Fig. 5). Our calculations indicate that contributions from shallow aqueous fluids are smaller, while inputs of slab melt are larger for Pagan samples, consistent with the changes expected with increasing slab depth. The fluid signature apparently develops in the source before the melt signature in the Pagan mantle source, so it is most likely inherited from forearc serpentinites ( $>40 \mathrm{~km}$ depth) dragged down along the slab/mantle interface.

Characterizing slab fluid and melt components for NW Rota-1 volcano. All the NW Rota-1 samples aside from those from East Knoll show evidence for inputs from a slab source with higher Mo/ $\mathrm{Nb}, \mathrm{Ba} / \mathrm{Nb}$, and $\mathrm{Cs} / \mathrm{Nb}$ than $\mathrm{DM}$ (Fig. 3). These samples are also characterized by unusually high $\mathrm{Ce} / \mathrm{Mo}$, which increases with decreasing Hf/Nd (Fig. 4e). Thus, we interpret the subduction input that fluxed the NW Rota-1 magma source to have been a hydrous melt. However, direct melting of a deeply subducted slab with a Mo isotopic composition like the eclogites from the Raspas Complex and Cabo Ortegal Complex cannot generate the Mo isotopic signature of NW Rota-1 samples (Fig. 5), so $\delta^{98 / 95}$ Mo must be higher at the slab surface at $200-220 \mathrm{~km}$ beneath NW Rota-1 than that at $\sim 170 \mathrm{~km}$ beneath SW Pagan. Fluids from serpentinite decomposition in the slab lithosphere, equilibrated with MORB-like overlying crust, are in theory the only source for heavy $\delta^{98 / 95} \mathrm{Mo}$ at such depths. The contrasting phenomena of $\delta^{98 / 95} \mathrm{Mo}$ decreases and increases for shallow ${ }^{32}(<65 \mathrm{~km})$ and deep $(>200 \mathrm{~km})$ subduction, respectively, indicate that the slab lithosphere fluid plays different roles in trigging dehydration/melting of the slab crust. At $>200 \mathrm{~km}$, both of the upper and lower slab crust may experience Mo loss as a result of early melting and fluid percolation, respectively, at shallow depth. We have calculated the $\delta^{98 / 95} \mathrm{Mo}$ and trace element compositions of a slab at $200 \mathrm{~km}(6 \mathrm{GPa})$. The lower ocean crust is assumed to have experienced early fluid percolation $(F=2 \%)$ and Mo loss at shallow depth with $\delta^{98 / 95} \mathrm{Mo}$ of $\sim-0.44 \%$, while the upper ocean crust is assumed to be the residue of melting $(F=10 \%)$ at $130 \mathrm{~km}(4 \mathrm{GPa})$ with $\delta^{98 / 95} \mathrm{Mo}$ of $\sim-0.9 \%$. Our calculations show that melting $(F=10 \%)$ of the upper oceanic crust (original $\delta^{98 / 95} \mathrm{Mo}=-0.9 \%$ o) with the addition of $2 \mathrm{wt} \%$ slab lithosphere fluid $\left(\delta^{98 / 95} \mathrm{Mo}=+0.06 \%\right.$ ) equilibrated with the lower crust can produce a slab melt with $\delta^{98 / 95} \mathrm{Mo}=\sim-0.07 \%$ and Ce/Mo of $\sim 51$ (Supplementary Fig. 5), similar to the components for NW Rota-1 samples and consistent with the hypothesis that slab lithosphere serpentinite breakdown can generate the fluids that trigger melting in deeply subducted slabs ${ }^{7,8,10,25,26}$. This interpretation is supported by the lower ${ }^{87} \mathrm{Sr} /{ }^{86} \mathrm{Sr}$ in primitive NW Rota-1 lavas relative to Pagan (Fig. 6a). The low Ce/Mo and high Hf/Nd signatures of the East Knoll samples indicate a mantle source with a strong hydrous fluid signature, assuming these samples have not experienced significant fractional crystallization of amphibole (Figs. 4e and 5d).

The role of sub-arc mantle heterogeneity can be characterized through correlations between $\mathrm{Nd}-\mathrm{Hf}$ isotopes and $\mathrm{Hf} / \mathrm{Nd}$ ratios (Supplementary Fig. 3), which suggest that the ambient mantle beneath NW Rota-1 may have lower $\varepsilon N d$ and $\varepsilon H f$ than the mantle beneath Pagan, resulting in two trends on $\delta^{98 / 95}$ Mo vs. $\varepsilon N d$ and $\varepsilon H f$, and $\varepsilon H f$ vs. $\varepsilon N d$ diagrams (Fig. 5). That the backarc mantle source may be more fertile than that beneath the volcanic front has also been observed in the Izu-Bonin $\operatorname{arc}^{46}$. Per constraints from $\varepsilon \mathrm{Hf}, \varepsilon \mathrm{Nd}$, and $\mathrm{Hf} / \mathrm{Nd}$, the NW Rota-1 mantle source would appear to include $0-5 \%$ slab melt, assuming its ambient mantle is more enriched than that of Pagan volcano (Fig. 5).

\section{Discussion}

Serpentinite breakdown has long been believed to play a crucial role in element transfer in subduction zones $8,15,16$. However, whether this serpentinite formed in the downgoing oceanic lithosphere or in the fore-arc mantle has been difficult to resolve ${ }^{27,28}$. Mo isotopes may help distinguish the respective roles of these two serpentinite sources.

Mo isotopes in NW Rota-1 lavas reflect a mantle source fluxed by hydrous melts generated via serpentinite breakdown in the subducting oceanic lithosphere, which triggered melting in the overlying subducted oceanic crust and sediments? ${ }^{7}$. This mechanism fails to explain observed Mo isotope variations in the Pagan lavas (Figs. 3 and 5). Mo isotope variations and their correlations with elemental proxies for aqueous fluid and hydrous melt require that the source material for Pagan melts was first metasomatized by an aqueous fluid that raised its $\delta^{98 / 95} \mathrm{Mo}$ and lowered its $\mathrm{Ce} / \mathrm{Mo}$ without affecting its $\mathrm{Hf} / \mathrm{Nd}$ or $\mathrm{Hf}$ isotopes. This fluid-modified source was then fluxed by hydrous melts, which lowered its $\delta^{98 / 95} \mathrm{Mo}, \varepsilon \mathrm{Hf}$, and $\mathrm{Hf} / \mathrm{Nd}$ and raised its $\mathrm{Ce} / \mathrm{Mo}$ (Fig. 5). The geochemistry of Pagan lavas points to a source contributor that records both fluid and melt inputs from the subducted slab. Serpentinite dragged down from the fore-arc mantle is the most likely candidate.

Figure 7 shows our preferred, Mo isotope-based model for the slab dehydration process beneath the Mariana arc. Shallow $(<80 \mathrm{~km})$ slab dehydration leads to partial serpentinization of the forearc mantle near the slab-mantle interface. This partly serpentinized forearc mantle is transported downward along the subducting slab, where it is further metasomatized by fluid and melt from the slab before serpentine totally breakdown at depth. Fluid/melt from the slab with high $\delta^{98 / 95} \mathrm{Mo}^{32}$ and largely MORB like $\mathrm{Pb}-\mathrm{Sr}$ isotopes ${ }^{8,10}$ are generated by the breakdown of serpentinite in the subducted lithospheric mantle. Dehydration of 


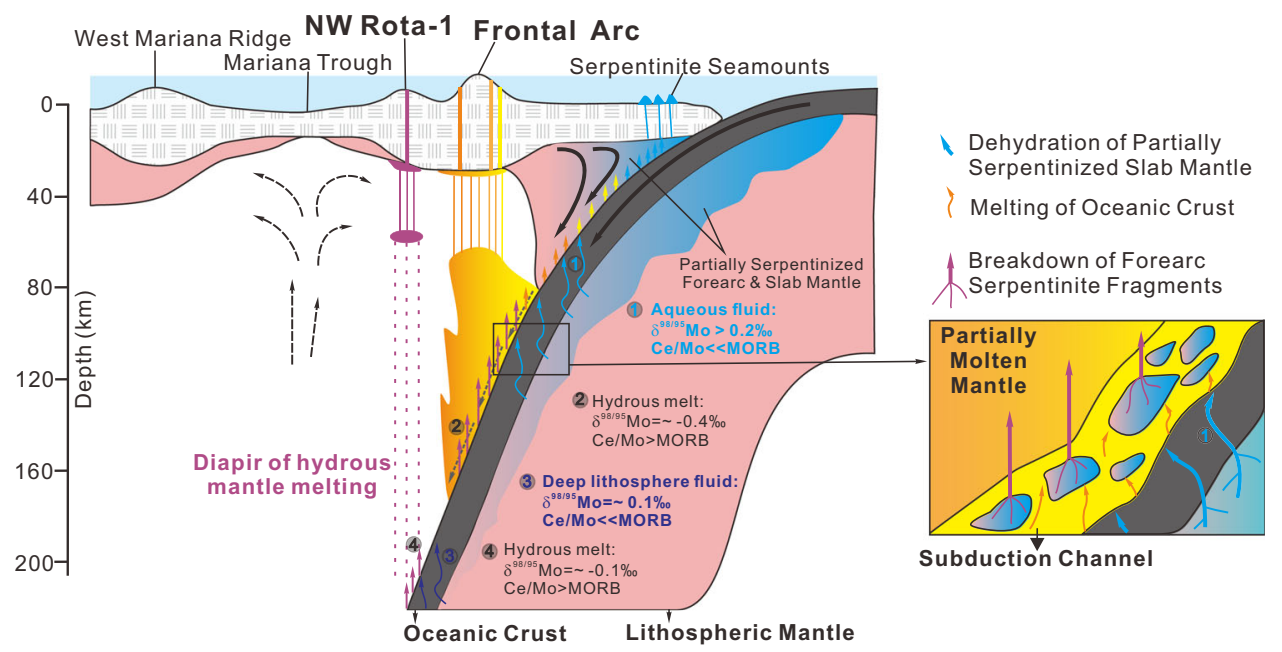

Fig. 7 Schematic cross-section through the Mariana arc, showing slab dehydration/melting processes. Shallow (<80 km) slab dehydration results in partial serpentinization of the forearc mantle. The partially serpentinized forearc mantle is then dragged down by the subducting slab and is further fluxed by fluid/melt from the slab at depth $>80 \mathrm{~km}$. Dehydration and melting of the slab were triggered by the breakdown of serpentinite in the subducted lithospheric mantle. Breakdown of multiple episodes of fluid/melt fluxed serpentinite in the subduction channel at $>80 \mathrm{~km}$ depth released its rehomogenized fluid/melt to the overlying mantle wedge and stimulated partial melting. Serpentinite being dragged down from the mantle wedge gradually decomposed in the subduction channel and is likely became totally exhausted by $200 \mathrm{~km}$ depth, then a breakdown of serpentinite in the slab lithosphere control the generation of slab melt at depth $>200 \mathrm{~km}$.

slab lithosphere serpentinites is expected to start at low temperature as a result of brucite breakdown, e.g., $300-400{ }^{\circ} \mathrm{C}$ at pressure $<2 \mathrm{GPa}$, according to results from the Erro-Tobbio meta-serpentinites in the Ligurian Alps of Italy ${ }^{23,24}$. This result is consistent with the estimated subducted slab Moho temperature of $\sim 300^{\circ} \mathrm{C}$ at about $100 \mathrm{~km}$ depth for the southern Mariana $\operatorname{arc}^{56}$. It is further supported by evidence from the Cabo Ortegal Complex eclogites, which have experienced long-term interaction with slab serpentinite fluids before reaching pressures $>1.7 \mathrm{GPa}$ and temperatures of $650-670{ }^{\circ} \mathrm{C}^{32}$. Dehydration of the slab lithosphere becomes less likely when it is not hot enough and brucite is exhausted at $<165 \mathrm{~km}$ depth. Breakdown of serpentinites that experienced multiple episodes of fluid/melt exchange in the subduction channel at $>80 \mathrm{~km}$ depth will release a rehomogenized fluid/melt into the overlying mantle wedge that can trigger partial melting. Melt segregation at $\sim 75 \mathrm{~km}$ depth $^{7}$ generates volcanic front basalts. As partially molten mantle is only likely to homogenize on scales of tens to a few thousand meters, hydrous melt contributions are likely to increase gradually in the mantle partial melting zone with slab depth and consequently with distance from the arc magmatic front. Down dragged subduction channel serpentinites are likely to be exhausted by $200 \mathrm{~km}$ depth, as seen in the disappearance of the forearc serpentinite signal in NW Rota-1 lavas. At depth $>200 \mathrm{~km}$, the temperature of the subducted slab Moho can reach $>550{ }^{\circ} \mathrm{C}^{56}$ which permits antigorite to break down in the slab lithosphere ${ }^{59}$. The mantle wedge is thus fluxed by a slab melt with high Ce/Mo due to early Mo depletion, triggering mantle melting and the diapiric rise of hydrous melt. These hydrous melts segregate from mantle partial melting zones at $\sim 65-50 \mathrm{~km}^{36}$ to generate basalts behind the arc volcanic front. Our model can also account for the Mo isotope variation of other Mariana and Izu volcanic front lavas (Fig. 4). This study suggests that serpentinite dragged down from the fore-arc mantle may play an important role in material transfer from the subducted plates towards the mantle wedge. It acts as an important intermediate carrier for slab fluid and melt transfers. Future new geochemical tracers and detailed geophysical observations can test the model presented in this paper.

\section{Methods}

Sample selection and preparation. The earliest record of magmatism in the Mariana subduction system is $\sim 52 \mathrm{Ma}$ from the initial convergence of the Pacific Plate toward the Philippine Sea Plate ${ }^{54,60,61}$. The arc later matured at $\sim 44 \mathrm{Ma}^{62,63}$ and experienced rifting and back extension at $\sim 30-15 \mathrm{Ma}$ and from $\sim 7 \mathrm{Ma}$ to present (see Straub et al. ${ }^{64}$ for review). The modern Mariana arc includes from west to east, the Mariana Trough (back-arc basin), the active Mariana arc, the old Mariana forearc (including the islands of Saipan, Tinian, Aguijan, Rota, and Guam), and the Mariana Trench (Fig. 1). The Mariana subduction system is nonaccretionary and the forearc is pervasively faulted, with numerous, large, and active serpentinite mud volcanoes derived from the shallow mantle wedge ${ }^{12,13}$. The active magmatic arc has been subdivided from north to south into the Northern Seamount Province, Central Island Province, and Southern Seamount Province ${ }^{65}$. Volcanic rock samples of this study are from Pagan and NW Rota-1 volcanos of the Mariana arc (Fig. 1). Pagan is one of the largest volcanoes along the volcanic front of the Central Island Province of the Mariana arc. It has a maximum elevation of $570 \mathrm{~m}$ (Mt. Pagan), with its submarine flanks descend to 2000-3000 m below sea level (Supplementary Fig. 1a). Samples from Pagan used in this study were collected in 2010 (cruise NT10-12), using ROV Hyper-Dolphin and R.V. Natsushima. Dive HPD1147 on the small knolls of NE Flank sampled two types of primitive clinopyroxene-olivine basalt (COB), COB1 (7.9-11.2 wt\% MgO) and COB2 (10.1-10.9 wt\% MgO), with the latter only $~ 500 \mathrm{~m}$ further away from the trench than the former. Some less evolved (8.2-9.4 wt\% MgO) basalts about $1000 \mathrm{~m} \mathrm{SW}$ away from the COB2 were also collected. Dive HPD1148 on the small knoll on its SW Flank recovered more evolved basalt $(5.4-7.5 \mathrm{wt} \% \mathrm{MgO})$. NW Rota-1 is a submarine volcano located about $40 \mathrm{~km}$ west of the volcanic front of the Southern Seamount Province. It has a conical shape, with its summit at about $520 \mathrm{~m}$ water depth (Supplementary Fig. 1c). Its base has a diameter of about $16 \mathrm{~km}$ at $2700 \mathrm{~m}$ water depth. Samples of this study from NW Rota-1 were collected in 2005 (cruise NT05-17) and 2009 (cruise NT09-02), using ROV Hyper-Dolphin and R.V. Natsushima. Dives HPD480 and HPD481 sampled porphyritic basalt and andesite $(2.8-8.2 \mathrm{wt} \% \mathrm{MgO})$ from the Summit areas at 520-1000 m depth. Dive HPD488 sampled COB (7.7-9.0 wt\% MgO) and plagioclase-olivine basalt (POB; 7.8-9.4 wt\% MgO) from the Eastern Flank of the volcano at 1500-2300 m depth. Dive HPD951 collected andesite lava flows (3.4-3.5 wt $\% \mathrm{MgO}$ ) from a knoll about $13 \mathrm{~km}$ east of the NW Rota-1 summit at $2000-2300 \mathrm{~m}$ depth. The Asùt Tesoru mud volcano samples examined in this study were recovered during International Ocean Discovery Program (IODP) Expedition 366. These samples were associated with upwelling pore fluids at $\mathrm{pH}>11.7$, indicating that they have not interacted with seawater $(\mathrm{pH}=\sim 8.1)$, and are thus representative of materials that have interacted with shallow, slab-derived serpentinizing fluid ${ }^{13}$. All samples were pulverized in an agate ball mill after sawing and jaw crushing. Major trace elements, mineral chemistry, and $\mathrm{Sr}-\mathrm{Nd}-\mathrm{Hf}-\mathrm{Pb}$ isotopes of the volcanic rock samples of this study have been discussed in detail in Tamura et al. ${ }^{36}$ and Tamura et al. ${ }^{7}$.

Mo isotope measurements. The chemical separation and mass spectrometry measurements of Mo isotopes were conducted at the State Key Laboratory of Isotope Geochemistry, Guangzhou Institute of Geochemistry, Chinese Academy of 
Sciences. In brief, an appropriate mass of sample powder was weighed out to provide $120 \mathrm{ng}$ of Mo. About $120 \mathrm{ng}$ of ${ }^{97} \mathrm{Mo}-{ }^{100}$ Mo double spike solution was added before digestion of the samples. The sample-spike mixture was digested by using $4 \mathrm{~mL}$ of $\mathrm{HF}$ and $2 \mathrm{~mL}$ of $\mathrm{HNO}_{3}$ in closed beakers at $140{ }^{\circ} \mathrm{C}$ overnight. Mo separation and purification were achieved using an extraction chromatographic resin of N-benzoyl-N-phenyl hydroxylamine manufactured in-house, following the protocols of $\mathrm{Li}$ et al. ${ }^{66}$ and Fan et al. ${ }^{67}$. After the sample matrix and interference, elements were removed, Mo isotope measurement was performed on a ThermoFisher Scientific Neptune-Plus multi-collector inductively coupled plasma mass spectrometer utilizing double spike analysis to correct for instrumental mass bias $^{68,69}$. Isotope measurements are made relative to a NIST SRM 3134 standard solution. The external reproducibility of the NIST SRM 3134 standard solution is at $0.06 \%$ o ( $2 \mathrm{SD}, n=51$ ) for the $\delta^{98 / 95} \mathrm{Mo}$ values. USGS rock reference materials AGV-2 and W-2a and IAPSO seawater standard were simultaneously processed with the samples to monitor accuracy and gave the $\delta^{98 / 95}$ Mo value of $-0.17 \pm 0.05 \%$ and $-0.03 \pm 0.06 \%$ and $+2.08 \pm 0.05 \%$, respectively. Repeat measurement of IAPSO seawater standard over the course of 6 months yielded a reproducibility of $2.06 \pm 0.09 \%$ ( $2 \mathrm{SD} ; n=24)$. Molybdenum concentrations were calculated from spiked isotope measurements. USGS rock reference materials AGV-2 and W-2a and IAPSO seawater standard yielded a concentration of 1.7 and $0.37 \mathrm{ppm}$ and $9.5 \mathrm{ppb}$, respectively. These results of Mo isotope and concentration are consistent with certified values and with the values reported by the previous studies ${ }^{66,70,71}$. Repeated digestion and analysis of individual rock samples of HPD1147R13 and HPD1148R19 yielded $\delta^{98 / 95}$ Mo difference $\leq 0.06 \%$ (Supplementary Data 1). The whole procedural blank for our analyses was $0.42 \pm 0.17 \mathrm{ng}$ (2 $\mathrm{SD}, n=3) \mathrm{Mo}$, far less than total Mo in the samples and standards.

\section{Data availability}

The authors declare that the data generated or analyzed during this study are included in this published article and its Supplementary Information files.

Received: 21 January 2021; Accepted: 23 September 2021; Published online: 14 October 2021

\section{References}

1. Stern, R. J., Fouch M. J. \& Klemperer S. L. An overview of the Izu-BoninMariana subduction factory. in Inside the Subduction Factory, Geophysical Monograph (ed Eiler, J.) 138, 175-222 (American Geophysical Union, 2003).

2. Elliott, T., Plank, T., Zindler, A., White, W. \& Bourdon, B. Element transport from slab to volcanic front at the Mariana arc. J. Geophys. Res. 102, 14991-15019 (1997).

3. Pearce, J. A., Stern, R. J., Bloomer, S. H. \& Fryer, P. Geochemical mapping of the Mariana arc-basin system: Implications for the nature and distribution of subduction components. Geochem. Geophys. Geosyst. 6, Q07006 (2005).

4. Ishikawa, T. \& Tera, F. Two isotopically distinct fluid components involved in the Mariana arc: Evidence from $\mathrm{Nb} / \mathrm{B}$ ratios and $\mathrm{B}, \mathrm{Sr}, \mathrm{Nd}$, and $\mathrm{Pb}$ isotope systematics. Geology 27, 83-86 (1999).

5. Hauff, F., Hoernle, K. \& Schmidt, A. Sr-Nd-Pb composition of Mesozoic Pacific oceanic crust (Site 1149 and 801, ODP Leg 185): Implications for alteration of ocean crust and the input into the Izu-Bonin-Mariana subduction system. Geochem. Geophys. Geosyst. 4, 8913 (2003).

6. Plank, T., Kelley, K. A., Murray, R. W. \& Stern, L. Q. Chemical composition of sediments subducting at the Izu-Bonin trench. Geochem. Geophys. Geosyst. 8, Q04I16 (2007).

7. Tamura, Y. et al. Mission immiscible: distinct subduction components generate two primary magmas at Pagan volcano, Mariana arc. J. Petrol. 55, 63-101 (2014).

8. Freymuth, H., Vils, F., Willbold, M., Taylor, R. N. \& Elliot, T. Molybdenum mobility and isotopic fractionation during subduction at the Mariana arc. Earth Planet. Sci. Lett. 432, 176-186 (2015).

9. Straub, S. M. Compilation of published major and trace elements and Sr-Nd$\mathrm{Pb}-\mathrm{Hf}$ isotope ratios of Quaternary-age arc volcanic rocks from 9 arc settings, Version 1.0. Interdiscip. Earth Data Alliance (IEDA). https://doi.org/10.1594/ IEDA/100664 (2017).

10. Klaver, M. et al. Sr isotopes in arcs revisited: tracking slab dehydration using $\delta^{88 / 86} \mathrm{Sr}$ and ${ }^{87} \mathrm{Sr} /{ }^{86} \mathrm{Sr}$ systematics of arc lavas. Geochim. Cosmochim. Acta 288, 101-119 (2020).

11. Ito, E., Stern, R. J. \& Douthitt, C. Insights into operation of the subduction factory from the oxygen isotopic values of the southern Izu-Bonin-Mariana Arc. Isl. Arc 12, 383-397 (2003).

12. Fryer, P. Evolution of the Mariana convergent plate margin system. Rev. Geophys. 34, 89-125 (1996).

13. Fryer, P. et al. Mariana serpentinite mud volcanism exhumes subducted seamount materials: implications for the origin of life. Philos. Trans. R. Soc. A 378, 20180425 (2020).
14. Benton, L. D., Ryan, J. G. \& Tera, F. Boron isotope systematics of slab fluids as inferred from a serpentine seamount, Mariana forearc. Earth Planet. Sci. Lett. 187, 273-282 (2001).

15. Savov, I. P., Ryan, J. G., D’Antonio, M., Kelley, K. \& Mattie, P. Geochemistry of serpentinized peridotites from the Mariana Forearc Conical Seamount, ODP Leg 125: Implications for the elemental recycling at subduction zones. Geochem. Geophys. Geosyst. 6, Q04J15 (2005).

16. Savov, I. P., Ryan, J. G., D’Antonio, M. \& Fryer, P. Shallow slab fluid release across and along the Mariana arc-basin system: Insights from geochemistry of serpentinized peridotites from the Mariana fore arc. J. Geophys. Res. 112, B09205 (2007).

17. Ishikawa, T. \& Nakamura, E. Origin of the slab component in arc lavas from across-arc variation of B and $\mathrm{Pb}$ isotopes. Nature 370, 205-208 (1994).

18. Straub, S. M. \& Layne, G. D. The systematics of boron isotopes in Izu arc front volcanic rocks. Earth Planet. Sci. Lett. 198, 25-39 (2002).

19. Pabst, S. et al. The fate of subducted oceanic slabs in the shallow mantle: Insights from boron isotopes and light element composition of metasomatized blueschists from the Mariana forearc. Lithos 132-133, 162-179 (2012).

20. Tonarini, S., Leeman, W. P. \& Leat, P. T. Subduction erosion of forearc mantle wedge implicated in the genesis of the South Sandwich Island (SSI) arc: Evidence from boron isotope systematics. Earth Planet. Sci. Lett. 301, 275-284 (2011).

21. Ryan, J. G. \& Chauvel, C. The subduction-zone filter and the impact of recycled materials on the evolution of the mantle. in Treatise on Geochemistry, 2nd edition (eds Holland, H. D. \& Turekian, K. K.) 3, 479-508 (Elsevier, 2014).

22. Cai, C., Wiens, D. A., Shen, W. \& Eimer, M. Water input into the Mariana subduction zone estimated from ocean-bottom seismic data. Nature 563, 389-392 (2018).

23. Plümper, O., John, T., Podladchikov, Y. Y., Vrijmoed, J. C. \& Scambelluri, M. Fluid escape from subduction zones controlled by channel-forming reactive porosity. Nat. Geosci. 10, 150-156 (2017).

24. Peters, D., Pettke, T., John, T. \& Scambelluri, M. The role of brucite in water and element cycling during serpentinite subduction-insights from Erro Tobbio (Liguria, Italy). Lithos 360-361, 105431 (2020).

25. Freymuth, H., Ivko, B., Gill, J. B., Tamura, Y. \& Elliott, T. Thorium isotope evidence for melting of the mafic oceanic crust beneath the Izu arc. Geochim. Cosmochim. Acta 186, 49-70 (2016).

26. Freymuth, H., Andersen, M. B. \& Elliott, T. Uranium isotope fractionation during slab dehydration beneath the Izu arc. Earth Planet. Sci. Lett. 522, 244-254 (2019).

27. Spandler, C. \& Pirard, C. Element recycling from subducting slabs to arc crust: a review. Lithos 170-171, 208-223 (2013).

28. McCaig, A. M. et al. No significant boron in the hydrated mantle of most subducting slabs. Nat. Commun. 9, 4602 (2018).

29. Bali, E., Keppler, H. \& Audetat, A. The mobility of W and Mo in subduction zone fluids and the Mo-W-Th-U systematics of island arc magmas. Earth Planet. Sci. Lett. 351-352, 195-207 (2012).

30. König, S., Wille, M., Voegelin, A. \& Schoenberg, R. Molybdenum isotope systematics in subduction zones. Earth Planet. Sci. Lett. 447, 95-102 (2016).

31. Li, H. Y. et al. Molybdenum and boron isotope evidence for fluid-fluxed melting of intraplate upper mantle beneath the eastern North China Craton. Earth Planet. Sci. Lett. 520, 105-114 (2019).

32. Chen, S. et al. Molybdenum systematics of subducted crust record reactive fluid flow from underlying slab serpentine dehydration. Nat. Commun. 10, 4773 (2019)

33. Villalobos-Orchard, J. et al. Molybdenum isotope ratios in Izu arc basalts: the control of subduction zone fluids on compositional variations in arc volcanic systems. Geochim. Cosmochim. Acta 288, 68-82 (2020).

34. Bezard, R., Fischer-Gödde, M., Hamelin, C., Brennecka, G. A. \& Kleine, T. The effects of magmatic processes and crustal recycling on the molybdenum stable isotopic composition of Mid-Ocean Ridge Basalts. Earth Planet. Sci. Lett. 453, 171-181 (2016).

35. Hayes, G. P. et al. Slab2, a comprehensive subduction zone geometry model Science 362, 58-61 (2018).

36. Tamura, Y. et al. Two primary basalt magma types from Northwest Rota-1 volcano, Mariana arc and its mantle diapir or mantle wedge plume. J. Petrol. 52, 1143-1183 (2011).

37. Davidson, J., Turner, S., Handley, H., Macpherson, C. \& Dosseto, A. Amphibole "sponge" in arc crust? Geology 35, 787-790 (2007).

38. Tiepolo, M., Oberti, R., Zanetti, A., Vannucci, R. \& Foley, S. F. Trace-element partitioning between amphibole and silicate melt. Rev. Mineral. Geochem. 67, 417-452 (2007).

39. Voegelin, A. R., Pettke, T., Greber, N. D., von Niederhäusern, B. \& Nägler, T. F. Magma differentiation fractionates Mo isotope ratios: evidence from the Kos Plateau Tuff (Aegean Arc). Lithos 190-191, 440-448 (2014).

40. Wille, M. et al. Molybdenum isotope variations in calc-alkaline lavas from the Banda arc, Indonesia: assessing the effect of crystal fractionation in creating isotopically heavy continental crust. Chem. Geol. 485, 1-13 (2018).

41. Shen, J. et al. Molybdenum isotope tracing petrogenesis of adakitic rocks and associated ore-forming process. Geochim. Cosmochim. Acta 300, 296-317 (2021). 
42. Willbold, M. \& Elliott, T. Molybdenum isotope variations in magmatic rocks. Chem. Geol. 449, 253-268 (2017).

43. Salters, V. J. M. \& Stracke, A. Composition of the depleted mantle. Geochem. Geophys. Geosyst. 5, Q05B07 (2004).

44. Gale, A., Dalton, C. A., Langmuir, C. H., Su, Y. \& Schilling, J.-G. The mean composition of ocean ridge basalts. Geochem. Geophys. Geosyst. 14, 489-518 (2013).

45. Hochstaedter, A. et al. Across-arc geochemical trends in the Izu-Bonin arc: contributions from the subducting slab. Geochem. Geophys. Geosys. 2, 2000GC000105 (2001).

46. Tollstrup, D. et al. Across-arc geochemical trends in the Izu-Bonin arc: contributions from the subducting slab, revisited. Geochem. Geophys. Geosyst. 11, Q01X10 (2010).

47. Kimura, J.-I. et al. Origin of cross-chain geochemical variation in Quaternary lavas from the northern Izu arc: using a quantitative mass balance approach to identify mantle sources and mantle wedge processes. Geochem. Geophys. Geosyst. 11, Q10011 (2010).

48. Wheat, C. G. et al. Data report: IODP Expedition 366 pore water trace element (V, Mo, Rb, Cs, U, Ba, and Li) compositions. Proc. IODP https://doi.org/ 10.14379/iodp.proc.366.201.2018 (2018).

49. Kessel, R., Schmidt, M. W., Ulmer, P. \& Pettke, T. Trace element signature of subduction-zone fluids, melts and supercritical liquids at $120-180 \mathrm{~km}$ depth. Nature 437, 724-727 (2005).

50. Pearce, J. A., Kempton, P. D., Nowell, G. M. \& Noble, S. R. Hf-Nd element and isotope perspective on the nature and provenance of mantle and subduction components in western Pacific arc-basin systems. J. Petrol. 40, 1579-1611 (1999).

51. Pearce, J. A., Kempton, P. D. \& Gill, J. B. Hf-Nd evidence for the origin and distribution of mantle domains in the SW Pacific. Earth Planet. Sci. Lett. 260, 98-114 (2007).

52. Chauvel, C., Marini, J.-C., Plank, T. \& Ludden, J. N. Hf-Nd input flux in the Izu-Mariana subduction zone and recycling of subducted material in the mantle. Geochem. Geophys. Geosyst. 10, Q01001 (2009).

53. Woodhead, J., Stern, R. J., Pearce, J., Hergt, J. \& Vervoort, J. Hf-Nd isotope variation in Mariana Trough basalts: the importance of "ambient mantle" in the interpretation of subduction zone magmas. Geology 40, 539-542 (2012).

54. Li, H. Y. et al. Radiogenic isotopes document the start of subduction in the Western Pacific. Earth Planet. Sci. Lett. 518, 197-210 (2019).

55. McCarthy, A. et al. Volcaniclastic sandstones record the influence of subducted Pacific MORB on magmatism at the early Izu-Bonin arc. Geochim. Cosmochim. Acta 296, 170-188 (2021).

56. Syracuse, E. M., van Keken, P. E. \& Abers, G. A. The global range of subduction zone thermal models. Phys. Earth Planet. Inter. 183, 73-90 (2010).

57. Adam, J. \& Green, T. Trace element partitioning between mica- and amphibole-bearing garnet lherzolite and hydrous basanitic melt: 1 . Experimental results and the investigation of controls on partitioning behaviour. Contrib. Mineral. Petrol. 152, 1-17 (2006).

58. Ishizuka, O. et al. Progressive mixed-magma recharging of Izu-Oshima volcano, Japan: a guide to magma chamber volume. Earth Planet. Sci. Lett. 430, 19-29 (2015)

59. Ulmer, P. \& Trommsdorff, V. Serpentine stability to mantle depths and subduction related magmatism. Science 268, 858-861 (1995).

60. Stern, R. J. \& Bloomer, S. H. Subduction zone infancy: examples from the Eocene Izu-Bonin-Mariana and Jurassic California arcs. Geol. Soc. Am. Bull. 104, 1621-1636 (1992).

61. Reagan, M. K. et al. Forearc ages reveal extensive short-lived and rapid seafloor spreading following subduction initiation. Earth Planet. Sci. Lett. 506, 520-529 (2019).

62. Ishizuka, O. et al. The timescales of subduction initiation and subsequent evolution of an oceanic island arc. Earth Planet. Sci. Lett. 306, 229-240 (2011).

63. Ishizuka, O., Taylor, R. N., Umino, S. \& Kanayama, K. Geochemical evolution of arc and slab following subduction initiation: a record from the Bonin Islands, Japan. J. Petrol. 61, egaa050 (2020).

64. Straub, S. M., Woodhead, J. D. \& Arculus, R. J. Temporal evolution of the Mariana Arc: mantle wedge and subducted slab controls revealed with a tephra perspective. J. Petrol. 56, 409-439 (2015).

65. Bloomer, S. H., Stern, R. J. \& Smoot, N. C. Physical volcanology of the submarine Mariana and Volcano arcs. Bull. Volcanol. 51, 210-224 (1989).

66. $\mathrm{Li}$, J. et al. Measurement of the isotopic composition of molybdenum in geological samples by MC-ICP-MS using a novel chromatographic extraction technique. Geostand. Geoanal. Res. 38, 345-354 (2014).

67. Fan, J. J. et al. High-precision molybdenum isotope analysis of low-Mo igneous rock samples by MC-ICP-MS. Chem. Geol. 545, 119648 (2020).

68. Siebert, C., Nägler, T. F. \& Kramers, J. D. Determination of molybdenum isotope fractionation by double-spike multicollector inductively coupled mass spectrometry. Geochem. Geophys. Geosyst. 2, 2000GC000124 (2001).
69. Zhang, L., Li, J., Xu, Y. G. \& Ren, Z. Y. The influence of the double spike proportion effect on stable isotope ( $\mathrm{Zn}, \mathrm{Mo}, \mathrm{Cd}$, and $\mathrm{Sn}$ ) measurements by multicollector-inductively coupled plasma-mass spectrometry (MC-ICP-MS). J. Anal. Spectrom. 33, 555-562 (2018).

70. Greber, N. D., Siebert, C., Nägler, T. F. \& Pettke, T. $\delta^{98 / 95}$ Mo values and molybdenum concentration data for NIST SRM 610, 612 and 3134: towards a common protocol for reporting Mo data. Geostand. Geoanal. Res. 36, 291-300 (2012).

71. Zhao, P. P. et al. Molybdenum mass fractions and isotopic compositions of international geological reference materials. Geostand. Geoanal. Res. 40, 217-226 (2016).

72. Kelley, K. A., Plank, T., Ludden, J. \& Staudigel, H. Composition of altered oceanic crust at ODP Sites 801 and 1149. Geochem. Geophys. Geosyst. 4, 8910 (2003).

73. Workman, R. K. \& Hart, S. R. Major and trace element composition of the depleted MORB mantle (DMM). Earth Planet. Sci. Lett. 231, 53-72 (2005).

74. Hart, S. R. A large-scale isotope anomaly in the Southern Hemisphere mantle. Nature 309, 753-757 (1984).

\section{Acknowledgements}

The Asut Tesoru seamount samples were provided by the International Ocean Discovery Program (IODP). We thank the crew of the JOIDES Resolution, the science team, and the technical support staff for IODP Expedition 366 for their efforts in sample recovery and shipboard characterization. H.Y.L., R.P.Z., J.L., and Y.G.X. were supported by the National Natural Science Foundation of China (NSFC Project 41922020), the Strategic Priority Research Program of the Chinese Academy of Sciences (Grant No. XDB42020201, XDB18000000), and the Key Special Project for Introduced Talents Team of Southern Marine Science and Engineering Guangdong Laboratory (Guangzhou) (GML2019ZD0202). J.R. was supported by a University of South Florida UNI-Nexus award for USF-GIGCAS faculty and student exchanges, as well as via IODP post-cruise support. This is contribution No. IS-3067 to GIG-CAS and UTD Geosciences contribution No. 1674.

\section{Author contributions}

H.Y.L. proposed the research plan, comprehensively interpreted the geochemical data, and drafted the primary paper. Y.T. supplied volcanic rock samples and the fundamental data. J.G.R. provided the serpentinite mud volcano samples and associated compositional data. R.P.Z. and J.L. conducted the Mo isotopic analyses. C.S., R.J.S., J.G.R., and Y.G.X. contribute to improving the interpretation of the data and the writing of the paper.

\section{Competing interests}

The authors declare no competing interests.

\section{Additional information}

Supplementary information The online version contains supplementary material available at https://doi.org/10.1038/s41467-021-26322-8.

Correspondence and requests for materials should be addressed to Hong-Yan Li.

Peer review information Nature Communications thanks Heye Freymuth and the anonymous reviewer(s) for their contribution to the peer review of this work. Peer reviewer reports are available.

Reprints and permission information is available at http://www.nature.com/reprints

Publisher's note Springer Nature remains neutral with regard to jurisdictional claims in published maps and institutional affiliations.

Open Access This article is licensed under a Creative Commons Attribution 4.0 International License, which permits use, sharing, adaptation, distribution and reproduction in any medium or format, as long as you give appropriate credit to the original author(s) and the source, provide a link to the Creative Commons license, and indicate if changes were made. The images or other third party material in this article are included in the article's Creative Commons license, unless indicated otherwise in a credit line to the material. If material is not included in the article's Creative Commons license and your intended use is not permitted by statutory regulation or exceeds the permitted use, you will need to obtain permission directly from the copyright holder. To view a copy of this license, visit http://creativecommons.org/ licenses/by/4.0/.

(C) The Author(s) 2021 